\title{
繁 \\ Parasites with zoonotic potential in canine fecal samples from Garanhuns, Pernambuco, Brazil
}

\author{
[Parasitos com potencial zoonótico em amostras fecais caninas de Garanhuns, \\ Pernambuco, Brasil]
}

\section{"Artigo Científico/Scientific Article"}

\author{
Lucia Oliveira de Macedo ${ }^{1}$, Marcos Antônio Bezerra Santos ${ }^{1}$, Breno Barros de Santana ${ }^{1}$, \\ Taylane Almeida Pereira ${ }^{2}$, Naiara Mirelly Marinho da Silva ${ }^{1}$, Leucio Câmara Alves ${ }^{3}$, \\ Rafael Antonio Nascimento Ramos ${ }^{1}$, Gílcia Aparecida de Carvalho ${ }^{1 *}$
}

\footnotetext{
${ }^{1}$ Unidade Acadêmica de Garanhuns, Universidade Federal Rural de Pernambuco, Garanhuns-PE, Brasil.

${ }^{2}$ Médica Veterinária Autônoma.

${ }^{3}$ Departamento de Medicina Veterinária, Universidade Federal Rural de Pernambuco, Recife-PE, Brasil

*Autor para correspondência/Corresponding author: E-mail: gilcia.acarvalho@yahoo.com
}

\begin{abstract}
Among the gastrointestinal parasites of dogs that present public health importance, the species of the genus Ancylostoma and Toxocara are the most frequently detected, and have been important cause of soil contamination. The aim of this study was to detect gastrointestinal parasites in dog's feces collected in households, streets and public squares of the city of Garanhuns, Pernambuco, Brazil. Fecal samples $(n=640)$ were collected in the environment and evaluated by parasitological methods of Willis-Mollay and Hoffman, Pons and Janer. Out of all samples, 51.09\% (327/640) were positive for gastrointestinal parasites. In particular, in $70.94 \%$ (232/327) of the samples were detected eggs of Ancylostoma spp., and in $11.01 \%(36 / 327)$ coinfection by Ancylostoma spp. and Toxocara canis. In conclusion, the presence of eggs of zoonotic parasites in feces collected from the environment in the city of Garanhuns represent a risk for the transmission of Cutaneous Larva Migrans and Visceral Larva Migrans for the human population.
\end{abstract}

Keywords: Ancylostoma spp.; Toxocara canis; zoonosis.

\section{Resumo}

Dentre os parasitos gastrintestinais de cães com importância em saúde pública, as espécies dos gêneros Ancylostoma e Toxocara são as mais frequentemente encontradas, e contaminam o solo. O objetivo desse estudo foi detectar parasitos gastrintestinais em fezes de cães coletadas em domicílios, ruas e praças públicas da cidade de Garanhuns, Pernambuco, Brasil. Amostras fecais $(n=640)$ foram coletadas no ambiente e avaliadas pelos métodos parasitológicos de Willis-Mollay e Hoffman, Pons and Janer. De todas as amostras, 51,09\% (327/640) foram positivas para parasitos gastrintestinais. Em particular, em 70,94\% (232/327) das amostras foram detectados ovos de Ancylostoma spp., e em 11,01\% (36/327) coinfecção por Ancylostoma spp. e Toxocara canis. Em conclusão, a presença de ovos de parasitos zoonóticos em fezes coletadas no ambiente na cidade de Garanhuns representa risco para a transmissão de Larva Migrans Cutanea e Larva Migrans Visceral para a população humana.

Palavras-chave: Ancylostoma spp.; Toxocara canis; zoonose.

\section{Introduction}

Several species of gastrointestinal parasites of dogs have been considered important threat for the public health, since they may be important cause of zoonosis in human population (Santos et al., 2007; Ferreira et al., 2016). Over the last decades, the habit of people to walk with animals, mainly dogs, in public places (e.g., squares and parks) have been increasing considerably. At the 
same time, the risk of human infection is also rising due to the elimination of eggs, larvae and/or oocysts of zoonotic parasites in the environment (Santarém et. al., 2004; Rinaldi et al., 2006; Tarsitano et al., 2010; Moura et al., 2013).

Among the parasites of dogs, the nematodes Toxocara canis and Ancylostoma spp. present great importance as the zoonotic agents of Visceral Larva Migrans (VLM) and Cutaneous Larva Migrans (CLM), respectively (Genari et al., 1999; Vasconcellos et al., 2006). The CLM is a very common manifestation in humans in tropical areas and it is mainly caused by larva of Ancylostoma braziliense and Ancylostoma caninum. Erythematous, vesicular, linear or meandering lesions and intense itch characterize this disease (Brenner and Patel, 2003). On the other hand, the VLM caused by $T$. canis and Toxocara cati is characterized as a systemic disease in which larvae migrate through different organs (e.g., liver, lungs, eyes and central nervous system) (RubinskyElefant et al., 2010).

For a long time, epidemiological studies of gastrointestinal parasites have been performed throughout Brazil. In general, the most common parasites detected are Ancylostoma spp. and T. canis followed by Trichuris vulpis, Strongyloides stercortalis, Dipylidium caninum, Giardia duodenalis. and Cystoisospora spp. (Funada et al., 2007; Moura et al., 2013; Ferreira et al., 2016).

Due to the importance of these parasites (e.g., Ancylostoma spp., T. canis, G. duodenalis and S. stercoralis) to public health, this study aimed to detect gastrointestinal parasites in feces of dogs collected from the environment in the municipality of Garanhuns, Pernambuco state, Brazil.

\section{Material and Methods \\ Study area}

The study was performed in the municipality of Garanhuns (latitude 8 $8^{\circ} 53^{\prime 2} 25^{\prime \prime}$ South and longitude 36 $29^{\prime} 34^{\prime \prime}$ West), located in the Agreste Microregion of state of Pernambuco, Northeast region of Brazil. The region presents annual average temperature of $24^{\circ} \mathrm{C}, 900$ meters above sea level, average rainfall of $147 \mathrm{~mm}$ (from $25 \mathrm{~mm}$ to $295 \mathrm{~mm}$ ), and air relative humidity of $90 \%$. Pernambuco Agency for Water and Climate (APAC, 2018).

The estimated population of dogs in the study area was determined based on the study by World Health Organization (WHO, 2005).

\section{Sample collection}

Canine fecal samples $(n=640)$ were collected in the environment, 297 in public roads, 271 in households and 72 in public squares around the municipality, for a period of two years.

The samples were placed in plastic vials, and stored into isothermal boxes at $4{ }^{\circ} \mathrm{C}$ until laboratory processing.

\section{Laboratorial procedures}

The evaluation of samples was performed by parasitological methods of Willis-Mollay simple flotation (Willis, 1921) and Hoffmann, Pons and Janer spontaneous sedimentation (Hoffmann et al., 1934). After sample processing, the material was examined at magnifications (10X and 40X). The identification of eggs and/or oocysts of parasites was performed according Taylor et al. (2010).

\section{Data analysis}

Data were statistically analyzed for absolute and relative frequencies. The Qui-square with Yates correction $\left(x^{2}\right)$ was used to compare the presence of gastrointestinal parasites and the location areas (squares, public roads and households) where the feces were collected. The significance level was set at 5\%. All analyzes were performed using the statistical software BioEstat version 5.0 (Ayres et al., 2007).

\section{Results}

Out of all samples analyzed, 51.09\% (327/640) were positive for the presence of gastrointestinal parasites. In particular, samples collected in households presented a positivity of $54.61 \%$ (148/271), followed by public roads with $52.53 \%(156 / 297)$ and $31.94 \%$ (23/72) for public squares $\left(x^{2}=12.152 ; \mathrm{p}=0.0023\right)$.

The general results of parasites detected are reported on Table 1. Ancylostoma spp. was the more frequent $(70.94 \% ; 232 / 327)$ parasite herein detected, as well as the coinfection between Ancylostoma spp. and T. canis $(11.00 \%$; 36/327) (Table 1).

\section{Discussion}

This study evaluated the presence of parasites in dogs' feces collected from the environment. The overall frequency herein observed was higher than others previously reported, in which frequencies of $37.16 \%$ (Ferreira et al., 2013) and $20.5 \%$ (Ferreira et al., 2016) have been reported. The differences herein observed may 
Table 1. Simple infections and coinfections detected in fecal samples of dogs in the city of Garanhuns, Pernambuco state, Brazil.

\begin{tabular}{|c|c|c|c|c|}
\hline Parasite & \multicolumn{3}{|c|}{ Frequency \% $\left(\mathbf{A F}^{1 / n}\right)$} & \multirow{2}{*}{$\begin{array}{c}\text { Freq. \% } \\
\text { Total (AF/N) }\end{array}$} \\
\hline & Public roads & Households & Squares & \\
\hline Ancylostoma spp. & $73.72(115 / 156)$ & $66.86(99 / 148)$ & $\begin{array}{c}78.26 \\
(18 / 23)\end{array}$ & $70.94(232 / 327)$ \\
\hline Toxocara canis & $2.56(4 / 156)$ & $10.13(15 / 148)$ & - & $5.50(18 / 327)$ \\
\hline Cystoisospora spp. & $0.64(1 / 156)$ & - & - & $0.30(1 / 327)$ \\
\hline Dipylidium spp. & $1.28(2 / 156)$ & - & - & $0.61(2 / 327)$ \\
\hline Strongyloides spp. & - & $0.68(1 / 148)$ & - & $0.30(1 / 327)$ \\
\hline Ancylostoma spp. and Toxocara canis & $7.05(11 / 156)$ & $14.20(21 / 148)$ & $17.39(4 / 23)$ & $11.00(36 / 327)$ \\
\hline Ancylostoma spp. and Cystoisospora spp. & $2.56(4 / 156)$ & - & - & $1.22(4 / 327)$ \\
\hline Ancylostoma spp. and Dipylidium spp. & $3.20(5 / 156)$ & $4.06(6 / 148)$ & - & $3.36(11 / 327)$ \\
\hline Ancylostoma spp. and G. duodenalis & - & - & $4.35(1 / 23)$ & $0.30(1 / 327)$ \\
\hline Ancylostoma spp. and Trichuris spp. & $1.28(2 / 156)$ & - & - & $0.61(2 / 327)$ \\
\hline Ancylostoma spp. and Strongyloides spp. & - & $0.68(1 / 148)$ & - & $0.30(1 / 327)$ \\
\hline Dipylidium spp. and Toxocara canis & $1.28(2 / 156)$ & $1.35(2 / 148)$ & - & $1.22(4 / 327)$ \\
\hline Cystoisospora spp. and Strongyloides spp. & - & $0.68(1 / 148)$ & - & $0.30(1 / 327)$ \\
\hline Cystoisospora spp. and Toxocara canis & - & $0.68(1 / 148)$ & - & $0.30(1 / 327)$ \\
\hline $\begin{array}{c}\text { Ancylostoma spp., Dipylidium spp. and } \\
\text { Toxocara canis }\end{array}$ & $1.92(3 / 156)$ & $0.68(1 / 148)$ & - & $1.22(4 / 327)$ \\
\hline $\begin{array}{c}\text { Ancylostoma spp. and Dipylidium spp. and } \\
\text { Trichuris spp. }\end{array}$ & $0.64(1 / 156)$ & - & - & $0.30(1 / 327)$ \\
\hline $\begin{array}{c}\text { Ancylostoma spp., Toxocara canis and } \\
\text { Strongyloides spp. }\end{array}$ & $0.64(1 / 156)$ & - & - & $0.30(1 / 327)$ \\
\hline $\begin{array}{l}\text { Ancylostoma spp., Toxocara canis, } \\
\text { Trichuris spp. and Cystoisospora spp. }\end{array}$ & $3.20(5 / 156)$ & - & - & $1.62(5 / 327)$ \\
\hline $\begin{array}{l}\text { Ancylostoma spp., Trichuris spp., } G . \\
\text { duodenalis. and Cystoisospora spp. }\end{array}$ & - & $0.68(1 / 148)$ & - & $0.30(1 / 327)$ \\
\hline Total \% & 100 & & & 100 \\
\hline
\end{tabular}

${ }^{1}$ Absolute Frequency

be related to several factors such as age of the animals, parasitic burden and the diagnostic method used in each study (Funada et al., 2007).

Interestingly, there was a higher frequency in households $(54.61 \%)$ when compared to the other collection areas. Most likely, the backyards were not paved and the contact between animals and soil favoured the environmental contamination as reported previously (Silva et al., 2019).

In a previous study performed in Paraná, a positivity rate of $60.1 \%$ was detected in household samples, followed by public roads $(52.53 \%)$ and squares (31.94\%) (Ribeiro et al., 2015). Some factors may contribute for these findings, for instance, in the households where the samples were collected, backyard with humid soil, protected against sunlight and with poor hygienic conditions were a common situation. The analysis of fecal samples collected from the environment has been performed worldwide where eggs of Toxascaris leonina, T. vulpis and oocysts/cysts of C. canis, Giardia spp. and Cryptosporidium spp. have been frequently detected (Veneziano et al., 2006; Rinaldi et al., 2008; Papini et al., 2009). The increase in the transmission of these parasites usually occurs under uncontrolled urbanized conditions, which are combined, to environmental changing and lack of basic sanitation (Lima et al., 2010).

The most frequent parasite was Ancylostoma spp. (70.94\%). These findings are similar to those from previous studies where Ancylostoma spp. were observed in $71.3 \%$ (Blazius et al., 2005) and $70.90 \%$ (Scaini et al., 2003) from the analyzed samples. 
Curiously, the nematode T. canis, common in tropical areas, was only found in $5.5 \%$ of the positive samples. Previous studies demonstrated a wide variation ranging from $1.2 \%$ (Castro et al., 2005 ) to $24.2 \%$ (Capuano and Rocha 2006) in the frequency of this nematode in fecal samples collected from the environment. This variation may occur due to the period (wet or dry) in which samples were collected, or due to the different methods of retrieval of eggs (Santana et al., 2015). It is important to highlight that Ancylostoma spp. and $T$. canis present great importance to public health, as they are the causative agents of CLM and VLM in human population.

Other parasites were detected in this study, but in lower frequencies (Table 1). For instance, $G$. duodenalis were found in households and public squares. Protozoa belonging to this genus presents zoonotic potential and is associated to intermittent or chronic diarrhoea in humans (Ballweber et al., 2010).

From a general perspective, in public roads, households and public squares the higher frequency found was for eggs of Ancylostoma spp., which present a potential risk for the human population. In areas studied of the city there are few or none structure of basic sanitation in the streets, and these situations favor the risks of infections in humans and animals due to the dissemination of eggs and oocysts of parasites with zoonotic potential.

\section{Conclusion}

In conclusion, there is the risk of transmission of CLM and VLM to the human population in Garanhuns due to the presence of canine feces in the environment contaminated with Ancylostoma spp. and T. canis. Therefore, it is important to perform the chemical control of gastrointestinal parasites in these animals, avoiding the environmental contamination and consequent dissemination of zoonotic gastrointestinal parasites. In addition, preventive measures of sanitary education, as well as personal hygiene are needed.

\section{Conflict of Interest}

The authors declare no conflict of interest.

\section{References}

Ayres, M.; Ayres Júnior, M.; Ayres, D.L.; Santos, A.A. BIOESTAT - Aplicações estatísticas nas áreas das ciências biomédicas. Ong Mamiraua. 2007.

Agência Pernambucana de Águas e Clima (APAC). Boletim do clima. Síntese climática, 6 (12): 134, 2018.

Ballweber, L.R.; Xiao. L.; Bowman, D.D.; Geoffrey, K.; Cama, V.A. Giardiasis in dogs and cats: update on epidemiology and public health significance. Trends in Parasitology, 26(4): 180-189, 2010.

Blazius, R.D.; Emerick, S.; Prophiro, J.S.; Romão, P.R.T.; Silva, O.S. Ocorrência de protozoários e helmintos em amostras de fezes de cães errantes da cidade de Itapema, Santa Catarina. Revista da Sociedade Brasileira de Medicina Tropical, 38(1): 73-74, 2005.

Brenner, M.A.; Patel, M.B. Cutaneous larva migrans: the creeping eruption. Cutis, 72(2): 111-115, 2003.

Capuano, D.M.; Rocha, G.M.D.E. Ocorrência de parasitas com potencial zoonótico em fezes de cães coletadas em áreas públicas do município de Ribeirão Preto, SP, Brasil. Revista Brasileira de Epidemiologia, 9(1): 81-86, 2006.

Castro, J.M.; Santos, S.V.; Monteiro, N.A. Contaminação de canteiros da orla marítima do Município de Praia Grande, São Paulo, por ovos de Ancylostoma e Toxocara em fezes de cães. Revista da Sociedade Brasileira de Medicina Tropical, 38(2): 199-201, 2005.

Ferreira, F.P.F.; Dias, R.C.F.; Martins, T.A.; Constantino, C.; Pasquali, A.K.S.; Vidotto, O.; Freire, R.L.; Navarro, I.T. Frequência de parasitas gastrointestinais em cães e gatos do município de Londrina, PR, com enfoque em saúde pública. Semina: Ciências Agrárias, Londrina, 34(6): 3851-3858, 2013.

Ferreira, J.I.G.S.; Pena, H.F.J.; Labruna, M.B.; Gennari, S.M. Occurrences of gastrointestinal parasites in fecal samples from domestic dogs in São Paulo, SP, Brazil. Revista Brasileira de Parasitologia Veterinária, 25(4): 435-440, 2016.

Funada, M.R.; Pena, H.F.J.; Soares, R.M.; Amaku, M.; Gennari, S.M. Frequência de parasitos gastrintestinais em cães e gatos atendidos em hospital-escola veterinário da cidade de São Paulo. Arquivo Brasileiro de Medicina Veterinária e Zootecnia, 59(5): 1338-1340, 2007.

Gennari, S.M; Kasai, N; Pena H.F.J; Cortez, A. Ocorrência de protozoários e helmintos em amostras de fezes de cães e gatos da cidade de São Paulo. Brazilian Journal of Veterinary 
Research and Animal Science, 36(2): 87-91, 1999.

Hoffmann, W.A.; Pons, J.A.; Janer, J.L. The sedimentation concentration method in schistosomiasis. Puerto Rico Journal Public Health, 9:281-298, 1934.

Lima, A.M.A.; Alves, L.C.; Faustino, M.A.G.; Lira, N.M.S. Percepção sobre o conhecimento e profilaxia das zoonoses e posse responsável em pais de alunos do pré-escolar de escolas situadas na comunidade localizada no bairro de Dois Irmãos na cidade do Recife (PE). Revista Ciência Saúde Coletiva, 15:1457-1464, 2010.

Moura, M.Q.; Jeske, S.; Vieira, J.N.; Correa, T.G.; Berne, M.E.A.; Villela, M.M. Frequency of geohelminths in publics quares in Pelotas, RS, Brazil. Revista Brasileira de Parasitologia Veterinária, 22(1): 175-178. 2013.

Papini, R.; Marangi, M.; Mancianti, F.; Giangaspero, A. O ccurrence and cystburden of Giardia duodenalis in $\operatorname{dog}$ faecal deposits from urbangreen areas: Implications for environmental contamination an drelate drisks. Preventive Veterinary Medicine, 92(1-2): 158-162, 2009.

Rinaldi, L.; Biggeri, A.; Carbone, S.; Musella, V.; Catelan, D.; Veneziano, V.; Cringoli, G. Canine faecal contamination and parasitic risk in the city of Naples (southern Italy). BMC Veterinary Research, 2(29): 2-6, 2006.

Ribeiro, C.M.; Lima, D.E.; Katagiri, S. Infecções por parasitos gastrintestinais em cães domiciliados e suas implicações na transmissão zoonótica. Veterinária e Zootecnia, 22(2): 238-244, 2015.

Rinaldi, L.; Maurelli, M.P.; Musella, V.; Veneziano, V.; Carbone, S.; DI Sarno, A.; Paone, M.; Cringoli, G. Giardia and Cryptosporidium in canine faecal samples contaminating an urban area. Research in Veterinary Science, 64(3): 13-415, 2008.

Rubinsky-Elefant, G.; Hirata, C.; Yamamoto, J.H.; Ferreira, M. Human toxocariasis: diagnosis, worldwide seroprevalences and clinical expression of the systemic and ocular forms. Annals Tropical Medicine and Parasitology, 104(1): 3-23, 2010.

Santana, B.B.; Silva, T.L.B.; Ramos, R.A.N., Alves, L.C.; Carvalho, G.A. Evaluation of Different Parasitological Techniques for Diagnosing Intestinal Parasites in Dogs. Open Journal of Veterinary Medicine, 5:19-24, 2015.
Santos, F.A.G.; Yamamura, M.H.; Vidoto, O.; Camargo, P.L. Ocorrência de parasitos gastrintestinais em cães (Canis familiaris) com diarreia aguda oriundos da região metropolitana de Londrina, Estado do Paraná, Brasil. Semina: Ciências Agrárias, 28(2): 257-268, 2007.

Santarém, V.A.; Giuffrida, R.; Zanin, G.A. Larva migrans cutânea: ocorrência de caso humanos e identificação de larvas de Ancylostoma spp. em parque público no município de Taciba, São Paulo. Revista da Sociedade Brasileira de Medicina Tropical, 37(2): 179-181, 2004.

Scaini, C.J., Toledo, R.N., Lovatel, R. Contaminação ambiental por ovos e larvas de helmintos em fezes de cães na área central de Balneário Cassino, Rio Grande do Sul. Revista da Sociedade Brasileira de Medicina Tropical, 36(5): 617-619, 2003.

Silva, N.M.M.; Santos, M.A.B.; Santana, B.B.; Macedo, L.O.; Alves, L.C.; Ramos, R.A.N.; Carvalho, G.A. Soil contamination by zoonotic gastrointestinal parasites of mammals in Garanhuns, Pernambuco, Brazil. Medicina Veterinária UFRPE, 13(1): 65-69, 2019.

Tarsitano, E.; Greco, G.; Decaro, N.; Nicassio, F.; Lucente, M.S.; Buonavoglia, C.; Tempesta, M. Environmental monitoring and analysis of faecal contamination in an urban setting in the city of Bari (Apulia region, Italy): health and hygiene implications. International Journal of Environmental Research and Public Health, 7(11): 3972-3986, 2010.

Taylor, M.A.; Coop, R.L.; Wall, R.L. Parasitologia Veterinária. $3^{\mathrm{a}}$ ed., Rio de Janeiro: Guanabara Koogan, 786p., 2010.

Vasconcellos, M.C.; Barros, J.S.L.; Oliveira, C.S. Parasitas gastrointestinais em cães institucionalizados no Rio de Janeiro, RJ. Revista de Saúde Pública, 40(2): 321-323, 2006.

Veneziano, V.; Rinaldi, L.; Carbone, S.; Biggeri, A.; Cringoli, G. Geographical Information Systems and canine faecal contamination: the experience in the city of Naples (southern Italy). Parasitologia, 48(1-2): 125-128, 2006.

Willis, H.H. A simple levitation method for the detection of hookworm ova. The Medical Journal of Australia, 8:375-378, 1921.

World Health Organization (WHO). WHO expert consultation on rabies. First report. Geneva: World Health Organization; 2005. 88p. 